\title{
EVALUASI DEPURASI TOTAL BAKTERI PADA KERANG DARAH DARI PERAIRAN DESA SUKAL, KABUPATEN BANGKA BARAT
}

\author{
Fika Dewi Pratiwi ${ }^{a, *}$, Eka Sari ${ }^{\mathrm{b}}$ \\ ${ }^{\text {a }}$ Program Studi Manajemen Sumberdaya Perairan, Fakultas Pertanian, Perikanan dan Biologi, \\ Universitas Bangka Belitung \\ ${ }^{\mathrm{b}}$ Program Studi Biologi, Fakultas Pertanian, Perikanan dan Biologi, Universitas Bangka Belitung \\ *Koresponden penulis: fikapratiwi.12@gmail.com
}

\begin{abstract}
Abstrak
Kerang darah hasil budidaya di perairan Desa Sukal, Kabupaten Bangka Barat banyak dijual di wilayah Provinsi Kepulauan Bangka Belitung. Kerang darah tersebut seringkali dijual tanpa ada perlakuan kontrol sanitasi maupun higienitasnya, selama budidaya maupun paska panen. Hal tersebut berpotensi adanya kontaminasi bakteri patogen pada produk kerang darah yang dapat membahayakan kesehatan konsumen. Penelitian ini bertujuan untuk menganalisis kandungan bakteri pada kerang darah yang berasal dari perairan Desa Sukal dan menganalisis kemampuan depurasi dengan sistem resirkulasi dengan waktu perlakuan 24 dan 48 jam pada kerang darah terhadap kandungan total bakteri. Penelitian ini dilakukan dengan metode eksperimen yang bersifat laboratoris dengan tiga kali ulangan untuk depurasi bakteri pada sampel kerang darah. Perlakuan depurasi sistem resirkulasi dengan menggunakan media air laut dengan salinitas $25 \mathrm{ppm}$ dan temperatur $29^{\circ} \mathrm{C}$ yang diberi sinar UV 15 watt dan $150 \mathrm{~g}$ kitosan yang berasal dari cangkang udang, dilakukan terhadap sampel kerang darah yang berasal dari perairan Desa Sukal untuk mengeliminasi adanya bakteri di dalamnya. Prinsip pengujian TPC yang digunakan sesuai SNI 01-2332.3-2006, sedangkan baku mutu yang digunakan adalah PerKa BPOM No. 16 tahun 2016. Hasil pengujian kerang darah yang berasal dari stasiun pertama menunjukkan bahwa kandungan TPC melebihi baku mutu yang telah ditetapkan. Uji independent $T$ test menunjukkan tidak terdapat perbedaan yang signifikan antara penurunan kandungan TPC sampel kerang darah dengan waktu depurasi 24 jam dengan waktu 48 jam.
\end{abstract}

Kata Kunci : Depurasi, Kerang Darah, Total Bakteri

\begin{abstract}
Blood clams cultured in Sukal Village West Bangka Regency sell in the market around Bangka Belitung Island Province. These blood clams often sell without sanitary and hygiene control treatment during cultivation or post-harvest. For that reason, the clams have the potential for pathogenic bacterial contamination that can harm the consumer's health. The study aimed to analyze the initial content of total bacteria (total plate count) in blood clam sample collected from Sukal Village and analyze the content of total bacteria (TPC) after depuration treatment for 24 hours and 48 hours. The method of this research was a laboratory experiment with three repetitions to depurate bacteria in blood clam samples. The depuration experiment followed the recirculating system for 24 hours and 48 hours. The UV light used to irradiate the natural saline water and chitosan from shrimp shell used as a filter and antibacterial agent. The temperature and salinity were constant at $29^{\circ} \mathrm{C}$ and $25^{\circ} \%$. Total plate count (TPC) method used in this research according to SNI 01-2332.3-2006, while PerKa BPOM No. 16 used as the quality standard of total bacteria content in blood clam. The result found that the blood clams collected from the first station contained total bacteria exceeded the established quality standards. Independent T-test showed that there was no significant difference between the reduction in the TPC content of blood clam samples with a depuration time of 24 hours and a time of 48 hours.
\end{abstract}

Keywords: Depuration, Blood clams, Total of Bacteria 


\section{PENDAHULUAN}

Kerang darah (Anadara granosa) merupakan jenis bivalvia yang hidup pada perairan laut dangkal sampai dengan daerah pasang surut. Kerang darah memiliki kandungan gizi yang tinggi, selain itu harganya terjangkau sehingga disukai oleh konsumen. Kandungan nutrisi tertinggi pada kerang darah adalah zat besi. Seratus gram kerang darah mengandung vitamin B12 sebanyak 33\% dari kebutuhan harian [1]. Ketersedian kerang darah di pasaran dapat diperoleh dari hasil penangkapan maupun budidaya. Budidaya kerang darah banyak dilakukan karena tekniknya mudah dan tidak memerlukan modal yang terlalu besar.

Salah satu kawasan yang menghasilkan kerang darah dari hasil budidaya adalah pesisir Desa Sukal, Kabupaten Bangka Barat, Provinsi Kepulauan Bangka Belitung. Ketersediaan kerang darah tersebut dapat mensuplai kebutuhan masyarakat di wilayah Provinsi Kepulauan Bangka Belitung. Budidaya kerang darah dilakukan oleh 212 rumah tangga di wilayah tersebut pada tahun 2015 dan menghasilkan 445,125 ton [2]. Meningkatnya jumlah pembudidaya dan permintaan pasar menjadikan usaha budidaya kerang darah tersebut mendapat dukungan untuk dikembangkan dari Dinas Kelautan Perikanan, Provinsi Kepulauan Bangka Belitung [3].

Permasalahan yang terjadi di dalam budidaya kerang darah salah satunya adalah masalah pencemaran akibat pengaruh aktivitas manusia di sekitarnya. Aktivitas manusia dapat menghasilkan limbah rumah tangga yang dapat mencemari perairan apabila mengandung bakteri pathogen. Hal tersebut akan berpengaruh pada kualitas kerang darah yang dibudidayakan pada suatu wilayah perairan, dikarenakan kerang darah merupakan filter feeder, sehingga dapat mengakumulasi bakteri yang bersifat pathogen seperti Escherichia coli dan Salmonella sp. pada jaringan atau dagingnya. Penelitian Zarkasi et al., [4] membuktikan bahwa terdapat beberapa jenis bakteri pada sampel kerang darah yang berasal dari pasar Malaysia. Devi et al., [5] juga menemukan beberapa jenis bakteri patogen pada kerang darah yang berasal dari Bantul, Yogyakarta yang dapat membahayakan kesehatan manusia. Kerang darah yang dijual di pasaran sering kali tidak melalui tahapan kontrol sanitasi maupun higienitas, sehingga apabila mengandung bakteri patogen dan dikonsumsi manusia maka dapat membahayakan kesehatan bahkan dapat menyebabkan penyakit.

Penurunan kandungan kontaminan termasuk bakteri di dalam kerang dengan cara depurasi merupakan hal penting dilakukan untuk peningkatan mutu, sehingga dapat terjamin keamanan pangan serta harga jual dapat ditingkatkan. Depurasi merupakan proses menempatkan kerang di dalam wadah yang berisikan air laut bersih untuk memaksimalkan penyaringan alami sebagai hasil pembersihan isi intestin yang dapat meningkatkan pemisahan zat kontaminan sehingga mencengah kontaminasi ulang [6]. Hasil penelitian Barile et al., [7] menunjukkan bahwa terdapat penurunan sebanyak 4 kali dari konsentrasi awal Vibrio .parahaemolyticus pada kerang Venus gallina setelah melalui depurasi sistem tertutup selama 36-48 jam dengan menggunakan UV dan ozon. Lees $e t$ al, [8 ] juga menyebutkan bahwa sistem depurasi juga telah banyak diterapkan pada skala komersil di beberapa negara maju seperti Australia, Prancis, Italia, Spanyol, dan Inggris untuk depurasi berbagai macam jenis kekerangan .

Berdasarkan latar belakang tersebut, peneliti tertarik mengkaji kandungan total bakteri pada kerang darah serta menganalisis kemampuan depurasi untuk menurunkan sampai dengan mengeliminasi total bakteri pada kerang darah. Oleh karena itu, penelitian ini bertujuan untuk menganalisis kandungan total bakteri pada kerang darah yang berasal dari hasil budidaya tambak di perairan Desa Sukal dan menganalisis kemampuan depurasi kerang darah terhadap kandungan total bakteri dengan kitosan dan sinar UV dengan waktu perlakuan yang berbeda. 


\section{MATERI DAN METODE}

\section{Metode Pengumpulan Data}

Sampel penelitian berupa sampel air laut dan sampel kerang darah diperlukan untuk eksperimen depurasi berasal dari perairan dusun Sukal, Kelurahan Belolaut, Kecamatan Muntok, Kabupaten Bangka Barat, Provinsi Kepulauan Bangka Belitung (Gambar 1). Sampel air laut dibutuhkan untuk media depurasi kurang lebih sebanyak 80 liter. Untuk sampel kerang yang digunakan pada penelitian, memiliki kisaran ukuran lebih dari $2 \mathrm{~cm}$. Sampel kerang berasal dari 3 staisun berbeda diperlukan untuk analisis awal kandungan total bakteri (TPC) dengan jumlah kurang lebih sebanyak $9 \mathrm{~kg}$, sedangkan untuk eksperimen depurasi dibutuhkan sampel kerang darah sebanyak 6 $\mathrm{kg}$. Sampel kerang yang akan digunakan untuk depurasi terlebih dahulu dibersihkan dari lumpur maupun kotoran yang menempel pada cangkang dengan menggunakan air laut.

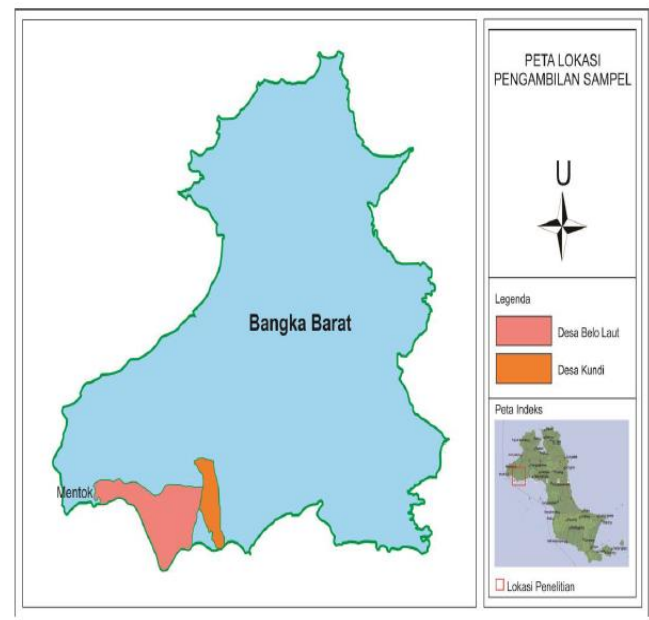

Gambar 1. Lokasi Pengambilan Sampel Penelitian

\section{Eksperimen Depurasi}

Analisis kandungan total bakteri (TPC) dilakukan pada sampel kerang yang berasal dari tambak di perairan desa Sukal pada 3 stasiun yang berbeda. Eksperimen depurasi dilakukan dengan skala laboratoris dilakukan setelahnya, untuk menguji efekttifitas depurasi kerang darah dengan media air laut yang bersalinitas 25 o/oo dan temperatur $29^{\circ} \mathrm{C}$. Eksperimen depurasi dilakukan dengan menggunakan media air laut yang diresirkulasi dengan perlakuan waktu depurasi yang berbeda yaitu 24 jam dan 48 jam. Kerang sebanyak tiga kilogram ditempatkan ke dalam masing wadah kecil, yang selanjutnya ditempatkan ke dalam tiga bak depurasi dengan volume masing-masing 20 liter yang dimodifikasi [9]. Setiap bak depurasi berisikan air laut yang telah dilewatkan filter berisikan 150 gram kitosan dari kulit udang serta instalasi lampu ultraviolet 15 watt. Proses depurasi dimulai dengan resirkulasi air laut selama 24 jam sebelum sampel kerang dimasukkan ke dalam bak depurasi dengan tujuan memfilter sampai dengan mengeliminasi kontaminan yang ada pada air laut.

\section{Analisis TPC (Total Plate Count) Bakteri}

Keamanan pangan dari kerang darah yang merupakan golongan moluska dari cemaran mikroba dapat dianalisis dengan melihat nilai TPC. Total plate count (TPC) atau angka lempeng total (ALT) merupakan perhitungan jumlah mikroba aerob mesofilik per gram atau per mili sampel yang ditentukan melalui prosedur standar. TPC dapat menunjukkan kualitas, kontaminasi maupun status higienis dari produk kerang darah yang dibudidayakan pada tambak. Analisis TPC atau ALT sampel kerang darah pada penelitian ini dilakukan di laboratorium milik BPOM Kota Pangkalpinang. Prinsip pengujian TPC yang digunakan sesuai SNI 01-2332.3-2006 tentang cara uji mikrobiologi bagian 3 terkait penentuan angka lempeng total (ALT) pada produk perikanan [10]. Untuk Baku Mutu yang digunakan adalah PerKa BPOM No 16 tahun 2016 [11]. Perhitungan yang digunakan dalam analisis TPC adalah sebagai berikut:

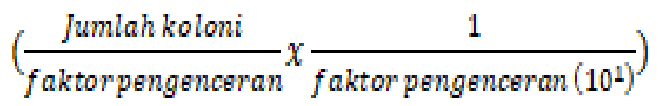




\section{Analisis Data}

Analisis deskriptif statistik (mean dan standard deviation) digunakan untuk mendeskripsikan variabel kuantitatif yang berupa data hasil analisis TPC sampel kerang darah pada tiga stasiun berbeda, sedangkan Independent $T$ test digunakan untuk menganalisis data hasil depurasi sampel kerang darah pada dua waktu yang berbeda. Analisis data penelitian tersebut dilakukan dengan menggunakan bantuan software SPSS Versi 23.0

\section{HASIL DAN PEMBAHASAN}

\section{TPC Bakteri Kerang Darah dari Desa Sukal}

Kerang darah merupakan golongan bivalvia yang banyak dikonsumsi oleh masyarakat. Beberapa kasus kontaminasi bakteri terjadi pada produk kekerangan. Salah satu penyebabnya adalah tidak adanya kontrol sanitasi maupun higienitas selama budidaya maupun paska panen. Ekawati dan Yusmiati [12] mendapati adanya kontaminasi pada kerang darah yang dijual di pasar Sidoarjo, Jawa Timur, terdapat Vibrio sp. serta kandungan TPC kurang dari $5 \times 10^{5}$ koloni/gram. Corralez et al., [13] mendapati bahwa kerang Crassostrea gigas dan Anadara spp. dari perairan Gulf of Nicoya, Costa Rica telah terkontaminasi oleh Escherichia coli, Salmonella spp., Vibrio parahaemolyticus. Produk kerang darah hasil budidaya di perairan Sukal, Kabupaten Bangka Barat yang didistribusikan ke pasar di wilayah Provinsi Kepulauan Bangka Belitung juga tanpa perlakuan kontrol sanitasi maupun higienitas. Hal tersebut terlihat pada saat observasi lapangan secara langsung, sehingga kerang darah tersebut berpotensi terkontaminasi oleh bakteri patogen, baik berasal dari habitatnya maupun perlakuan setelah panen.

Tabel 1 di bawah ini menunjukkan hasil analisis TPC sampel kerang darah yang diambil dari 3 tambak berbeda yang berada perairan Desa Sukal, Kabupaten Bangka Barat. Analisis TPC dilakukan dengan lima kali ulangan untuk setiap stasiunnya. Hasil analisis menujukkan terdapat sampel yang berasal dari stasiun kesatu kandungan TPC melebihi ambang batas yang diperbolehkan, sedangkan pada stasiun kedua dan ketiga, nilai TPC masih di bawah standar baku mutu yang ditetapkan oleh PerKa BPOM No.16 tahun 2016 (koloni/gram $=2 ;$ minimum $=10^{5}$; maksimum $\left.=10^{6}\right)$. Hal tersebut diduga karena adanya pemukiman di sekitar pesisir Desa Sukal yang dapat memberikan kontribusi kontaminan bakteri terhadap tambak di pesisir pantai. Hasil analisis statistik deskriptif menggunakan SPSS yang menunjukkan kandungan TPC minimum dari sampel kerang adalah $2,25 \times 10^{3} \quad \mathrm{koloni} / \mathrm{g}$, sedangkan maksimum yang ditemukan yaitu $9,1 \times 10^{5}$ koloni/g.

Tabel 1. Analisis TPC Sampel Kerang Darah

\begin{tabular}{lll}
\hline St & Uji & $\begin{array}{c}\text { Hasil } \\
\text { (koloni/g) }\end{array}$ \\
\hline 1 & TPC & $\mathrm{n} 1=3,5 \times 0^{5}$ \\
& $\mathrm{n} 2=9,1 \times 10^{5}$ \\
$\mathrm{n} 3=1,6 \times 10^{5}$ \\
$\mathrm{n} 4=3,5 \times 10^{4}$ \\
& $\mathrm{n} 5=5,4 \times 10^{3}$ \\
& & $\mathrm{n} 1=1,2 \times 10^{4}$ \\
& $\mathrm{n} 2=3,6 \times 10^{3}$ \\
& & $\mathrm{n} 3=6,5 \times 10^{4}$ \\
& TPC $4=1,2 \times 10^{4}$ \\
& $\mathrm{n} 5=1,8 \times 10^{4}$ \\
& & $\mathrm{n} 1=2,25 \times 10^{3}$ \\
& & $\mathrm{n} 2=3,6 \times 10^{3}$ \\
& & $\mathrm{n} 3=7 \times 10^{3}$ \\
& TPC & $\mathrm{n} 4=9,4 \times 10^{3}$ \\
& & $\mathrm{n} 5=1 \times 10^{4}$ \\
& & \\
\hline
\end{tabular}

\section{TPC Bakteri Kerang Darah setelah Depurasi}

Depurasi kerang darah merupakan suatu proses alami yang dapat dilakukan untuk mengurangi sampai dengan menghilangkan kontaminan dalam kerang-kerangan agar aman dikonsumi dan kandungan kontaminan yang ada di bawah baku mutu yang ditetapkan [14]. Depurasi yang dilakukan di dalam penelitian ini menggunakan sistem resirkulasi air laut, sinar UV 15 Watt dan kitosan 150 gram yang berasal dari cangkang udang. Gambar 2 dan Tabel 2 berikut ini, menunjukkan kandungan TPC sampel kerang 
darah dari stasiun pertama yang telah melalui proses depurasi dengan sistem resirkulasi dan waktu perlakuan yang berbeda. Hasil tersebut menunjukkan terdapat penurunan kandungan TPC pada sampel kerang darah setelah depurasi baik selama 24 jam maupun 48 jam, yang nilainya lebih rendah dari pada sebelum perlakuan depurasi. Berdasarkan hasil independent $T$ test, menunjukkan tidak terdapat perbedaan yang siginifikan antara penurunan kandungan TPC dengan waktu depurasi 24 jam maupun 48 jam. Hal tersebut ditunjukkan dengan nilai sig (2-tailed) (0.165) $>0.05$.

Penggunaan sinar UV telah banyak di gunakan pada beberapa negara seperti Inggris, Amerika dan Eropa untuk depurasi produk kekerangan skala industri atau komersil [15]. Penggunaan sinar UV dikategorikan aman digunakan untuk depurasi karena tidak membahayakan organisme yang didepurasi maupun lingkungannya, termasuk manusia serta tidak menghasilkan residu bahan kimia yang berbahaya [16]. Penggunaan kitosan sebagai filter dalam depurasi dikarenakan selain berfungsi sebagai adsorben juga dapat berfungsi sebagai agen antimikroba dan antibakteri [17].

Hasil depurasi menunjukkan terdapat penurunan kandungan TPC kerang darah setelah dilakukan depurasi sampel kerang darah, sehingga kandungan TPC nya di bawah baku mutu yang telah ditetapkan oleh standar PerKa BPOM No.16 Tahun 2016.

Tabel 2. Kandungan TPC sebelum dan setelah Depurasi

\begin{tabular}{lcll}
\hline No & $\begin{array}{c}\text { TPC } \\
\text { sebelum } \\
\text { depurasi }\end{array}$ & $\begin{array}{l}\text { TPC } \\
\text { Setelah } \\
\text { Depurasi } \\
\mathbf{2 4} \text { jam }\end{array}$ & $\begin{array}{l}\text { TPC } \\
\text { Setelah } \\
\text { Depurasi } \\
\mathbf{4 8} \text { jam }\end{array}$ \\
\hline 1 & $\mathrm{n} 1=3,5 \times 10^{5}$ & $\mathrm{n} 1=6,5 \times 102$ & $\mathrm{n} 1=2 \times 103$ \\
2 & $\mathrm{n} 2=9,1 \times 10^{5}$ & $\mathrm{n} 2=1,6 \times 102$ & $\mathrm{n} 2=2 \times 103$ \\
3 & $\mathrm{n} 3=1,6 \times 10^{5}$ & $\mathrm{n} 3=1 \times 103$ & $\mathrm{n} 3=8,7 \times 102$ \\
4 & $\mathrm{n} 4=3,5 \times 10^{4}$ & $\mathrm{n} 4=1,5 \times 103$ & $\mathrm{n} 4=2,9 \times 104$ \\
5 & $\mathrm{n} 5=5,4 \times 10^{3}$ & $\mathrm{n} 5=1,2 \times 103$ & $\mathrm{n} 5=6,2 \times 104$ \\
\hline
\end{tabular}

Hasil uji independent $T$ test menunjukan bahwa tidak terdapat perbedaan yang signifikan antara penurunan kandungan TPC hasil depurasi kerang darah selama 24 jam dengan 48 jam. Hasil depurasi 24 jam menunjukkan bahwa kerang darah masih terlihat segar, aktif membuka cangkangnya serta tidak ada kerang yang mati. Namun, pada saat depurasi 48 jam berlangsung, terdapat penurunan kondisi kerang dimana respon buka tutup cangkang lebih lambat. Keefektikan perlakuan depurasi dipengaruhi oleh beberapa hal diantaranya yaitu desain depurasi digunakan [18], jenis atau spesies organisme [19], fisiologi organisme [20], temperatur dan salinitas [21], konsentrasi awal dan tipe kontaminan yang ada pada organisme serta karakteristik geografi dan musim setempat [22].

Secara fisologi, kerang darah yang merupakan filter feeder, hidup pada daerah yang berlumpur serta dipengaruhi oleh pasang surut. Proses depurasi sangat berkaitan dengan karakteristik organisme, sehingga kerang darah tidak dapat terendam di dalam air laut terlalu lama pada saat depurasi. Apabila terdapat kematian kerang darah pada saat depurasi, maka dapat menurunkan kualitas air serta dapat mengkontaminasi ulang kerang darah. Hal tersebut sesuai dengan penelitian Lee et al., [15] yang menyebutkan bahwa bakteri patogen bisa survive selama proses depurasi di dalam feses kerang, sehingga mengakibatkan kontaminasi ulang apabila feses yang telah diekskresikan, diserap kembali oleh kerang tersebut. Berdasarkan hasil uji laboratorium, kandungan TPC kerang darah melebihi baku mutu perKa BPOM, akan tetapi belum teridentifikasi jenis-jenis bakteri patogen maupun kontaminan lainnya di dalam jaringan kerang darah. Oleh karena itu perlu dikaji lebih mendalam mengenai jenis-jenis bakteri patogen maupun virus yang ada di dalam produk kerang darah. Perlakuan depurasi kerang untuk virus akan berbeda dengan depurasi untuk bakteri. Waktu yang lebih lama serta desain depurasi yang berbeda diperlukan untuk menghilangkan jenis virus pada produk kekerangan [7]. Hal tersebut memerlukan kajian lebih mendalam mengenai desain depurasi yang sesuai dengan jenis kontaminan yang ingin dihilangkan.

$$
\text { Eksperimen depurasi dengan }
$$

menggunakan sistem flow-through system juga perlu diteliti lebih lanjut terkait dengan tingkat keefektifannya dibandingkan dengan sistem resirkulasi yang telah dilakukan. 
Langkah preventif juga dapat dilakukan di lapangan berupa upaya kontrol sanitasi yang sesuai selama budidaya maupun paska panem. Regulasi dari pemerintah setempat terkait polusi organik maupun anorganik di sekitar area budidaya juga perlu diindahkan. Hal tersebut dilakukan dalam rangka menjaga kemananan pangan serta meningkatkan mutu produk kerang darah yang dijual di pasar, sehingga konsumen mendapatkan nilai manfaat yang baik serta pembudidaya juga dapat menjaga keberlangsungan usaha budidaya kerang darah di perairan Sukal.

\section{KESIMPULAN}

Simpulan yang dapat diambil dari penelitan ini yaitu kandungan TPC sampel kerang darah yang berasal dari stasiun pertama, perairan desa Sukal, Kabupaten Bangka Barat melebihi baku mutu yang telah ditetapkan (PerKa BPOM No.16 tahun 2016). Hasil Uji Independent $T$ test menunjukkan tidak terdapat perbedaan yang signifikan antara penurunan kandungan TPC sampel kerang darah setelah melalui depurasi sistem resirkulasi selama 24 jam maupun 48 jam.

\section{UCAPAN TERIMAKASIH}

Penulis mengucapkan terimakasih kepada Kemenristek DIKTI atas dana penelitian Penelitian Dosen Pemula yang diberikan serta Universitas Bangka Belitung yang memfasilitasi penulis untuk mendapatkan dana penelitian tersebut. Penulis juga mengucapkan terimakasih banyak atas bantuan dan dukungan dari Dwi Yanto, S.T dari awal sampai dengan berakhirnya kegiatan penelitian.

\section{DAFTAR PUSTAKA}

[1] Afiati, N, "The Ecology of Two Species of Blood Clams Anadara granosa (L.) And Anadara Antiqua (L.) In Central Java, Indonesia," Disertasi. University of Wales. Bangor. United Kingdom. 1994.
[2] Antaranews.com/berita/ 576884/usaha-budidaya-kerang semakin-diminati. 8 Agustus 2019

[3] Dinas Kelautan dan Perikanan, "Rencana Strategis Dinas Kelautan dan Perikanan 2017-2022," Provinsi Kepulauan Bangka Belitung. 2017

[4] Zarkasi, K.M, K.F Sheng, T.F Nazari, N.A Muhammad and A.A Abdullah. Bacterial community diversity associated with blood cockle (Anadara granosa) in Penang, Malaysia. Scientia Bruneiana, Vol. 16, No. 2, hal 41-47. 2017

[5] Devi A.R, A. Susilowati dan R. Setyaningsih. Enumerasi dan uji patogenitas Vibrio sp. yang terdapat pada kerang darah (Anadara gramosa) di kawasan pantai wisata Yogyakarta. Pros Sem Nas Masy Biodiv Indon No. 5, hal:357-361.2018.

[6]

Lee, R. A, Lovatelli dan L. Ababouch, "Bivalve Depuration: Fundamental and Practical Aspects," Food and Agriculture Organization of The United Nations. ISBN 978-92-5106006-3. Rome.pp.161. 2008.

[7] Barile N.B , E. Nerone, M. Scopa dan S. Recchi. Depuration of Striped Venus Clams Following Artificial Vibriones Contamination. Ital. J. Food Sci., vol. 30, hal. 602:613.2018

[8] Lees D, A.Younger dan B. Dore. Depuration and Relaying. World Health Organization(WHO). Safe Management of Shellfish and Harvest Waters.Editor: G. Rees,K. Pond,D. Kay, J. Bartramand dan J. Santo Domingo.ISBN:9781843392255.IWA Publishing, London,UK. 2010

[9] Barile N.B, M Scopa, E Nerone, G Mascilongo, S Recchi, S Cappabianca dan L Antonetti, " Study of the Efficacy of a Closed Cycle 
Depuration System on Bivalve Molluscs," Vetenaria Italiana. Vol.45, No.4, hal.555-566. 2009.

[10]

Badan Standarisasi Nasional, "Cara Uji Mikrobiologi-Bagian 3:Penentuan Angka Lempeng Total (ALT) pada produk perikanan," SNI 01-2332.32006. Badan Standarisasi Nasional. Jakarta. 2006.

[11] Peraturan Kepala Badan Pengawas Obat dan Makanan Republik Indonesia, "PerKa BPOM No.16 tahun 2016. Kriteria Mikrobiologi," 2016.

[12] Ekawati E.R dan S N H Yusmiati, "Detection of Salmonella sp., Vibrio sp. and total plate count bacteria on blood cockle (Anadara granosa)," International Symposium on Food and Agro-biodiversity (ISFA) 2017. IOP Conf. Series: Earth and Environmental ence 102. 012086. 2018.

[13] Corrales, L.A.V, C.M Vindas, O.P Prieto dan G.Z Calero, "Preliminary Assessment of Small Scale Bacterial Depuration of Crassostrea gigas and Anadara spp., Gulf of Nicoya, Costa Rica. Rev. Mar. Cost. ISSN 1659455X, Vol.5, hal.107-117. 2013.

[14] Terence O, B. Mark, S. Mary, M. Daniel, O. Michael dan R. Cillian, “ Depuration centre management. Course notes," ARCHIMER. Ifremer's institutional repository. 1995.

[15] McLeod C, D.Polo, J.C Le Saux dan F.S. Le Guyader, "Final Report: Evaluating the effectiveness of depuration in removing norovirus from oysters," Seafood Safety Assessment Ltd. and the French Research Institute for Exploitation of the Sea. 2017

[16] Sorio, J dan J. Peralta, "Evaluation of a Small Scale UV-treated Recirculating Depuration System for Oysters (Crassostrea iredalei)," International Conference on Fisheries and Aquatic Sciences. 2018

[17] Ahmed S, M.Ahmad dan S. Ikram, "Chitosan: A Natural Antimicrobial Agent- A Review," Journal of Applicable Chemistry, Vol.3, No.2, hal. 493-503. 2014

[18] Otwell W.S, G.E Rodrick dan R.E Martin, "Molluscan Shellfish Depuration," CRC Press. Boca Raton. 398 p. 1991.

[19] Lee R, Lovatelli, A. dan Ababouch, L, "Depuración de bivalvos: aspectos fundamentales y prácticos," FAO Documento Técnico de Pesca No. 511. Rome, Italy: FAO. 2010.

[20] Cusson, M, R Tremblay, G. Daigle, dan M Roussy, "Modeling the depuration potential of blue mussels (Mytilus spp.) in response to thermal shock," Aquaculture, Vol.250, hal. 183-193, 2005

[21] Love, D. C, G. L Lovelace, dan M. D. Sobsey, "Removal of Escherichia coli, Enterococcus fecalis, coliphage MS2, poliovirus, and hepatitis A virus from oysters (Crassostrea virginica) and hard shell clams (Mercinaria mercinaria) by depuration," Int. J. Food Microbiol., Vol. 143, hal. 211217, 2010.

[22] Oliveira, J., Cunha, A., Castilho, F., Romalde, J. L. dan Pereira, M. J, “ Microbial contamination and purification of bivalve shellfish: Crucial aspects in monitoring and future perspectives-A mini review," Food Control, Vol. 22, No.6, hal. 805816. 2011 